\title{
Sandra Burr
}

\section{Whoa! Reining in the research doctorate in creative practice}

\author{
Abstract \\ Faced with multiple requirements not only to establish a \\ research question and a method of inquiry, but also to meet the \\ complex demands of a bi-partite exegetical/creative \\ dissertation, creative practice often presents as an unnavigable \\ wilderness to novice PhD students. Sometimes circumstances \\ arise causing candidates to lose their way and they become \\ disconnected from their research as theory and practice \\ diverge. Such difficulties may be overcome by repairing the \\ interface between theory and practice through the development \\ of a personal research ethos. Establishing a philosophical \\ approach to ethical creative practice may restore candidate \\ confidence by validating their positions as researchers. The \\ author describes how by pausing and drawing on parallels \\ between creative practice and creative horsemanship she was \\ able to make sense of her own creative practice and restore a \\ project that had threatened to wander dangerously off course.
}

\section{Introduction}

Creative practice in academia is an ongoing topic of concern and interest to practitioners, teachers, students and examiners alike. A growing body of scholarship concentrates on tracking the philosophical approaches to creative scholarship and the various ways and means of producing the creative thesis (see for example Costello 2005, TEXT Special Issue No 3, 2004, Woods 2007). Knotty questions such as how the exegesis relates to the creative work are much examined (Arnold 2005, Dally et al 2004, Guest 2005, Milech \& Schilo 2004, Ryan 2005), yet solutions remain fugitive. What is clear is that, while guidelines exist, there are no absolutely right or wrong ways to produce a creative doctoral dissertation.

This lack of certitude leaves candidates with considerable freedom to devise solutions specific to the vagaries of their own unique projects. However, creative practitioners caught up in the particulars of their own research need to be mindful that research never happens in isolation. To borrow from the domain of ecophilosophy (Booth 2007), while creative practice is just one part 
of the interconnected and interdependent universe, the elements of research are also just some of the many circles within circles that make up the complex cosmos of creative practice. One danger in over-focussing on individual aspects of the project is that practitioners may lose the all-important bird's eye view of their research landscape and with it their sense of direction. Like many creative doctoral candidates I became sidetracked by particular aspects of my research and struggled to remain connected to the project as a whole. Only by stepping back and taking a wider view have I been able to develop a personal ethos of creative practice that allowed for the possibility that all the pieces might eventually be stitched together. What follows is a contribution to this discussion on the theory of creative practice that draws upon the similarities discovered in both my journey as a creative $\mathrm{PhD}$ candidate, and my life as a horse owner who always looks for solutions outside the square.

\section{My research}

My project is concerned with examining the relationship between women and horses and, like much cultural research, stems from a lifelong passion - in my case, for horses. Contemporary Australian horsewomen have received almost no academic attention and their ways of knowing and being with horses are largely unexplored. To address this lack I constructed a multi-method platform typical of the hybrid nature of cultural research (Ryan 2005, Saukko 2003) with a suite of interrogative methods, drawing upon texts, a questionnaire survey, interviews, participant observation and my own lived experiences. I imagined my data-gathering techniques would identify recurring themes and insights into the horse/woman bond, and I intended to fit the data to the required exegetical/creative product paradigm by placing the horsewomen's narratives, with appropriate theoretical commentary, into the exegesis, and my personal narratives into a thematically matched creative work. I believed that the discursive patterns would be the causal link bridging the divide between the exegesis and the creative product. With this plan in place, like Brian Dibble's ideal student (Dibble 2006: 113) I saw myself steadily reaching my goal without much trauma or difficulty.

\section{The data problem}

Gathering, ordering and analysing information provided a point of entry into the project, not only as a means of filling existing gaps in knowledge about Australian horsewomen, but also because, as a librarian and researcher, it was something that I knew how to do. By the end of the first year of my candidature I had a reasonable set of data and I used it to produce a poster ('Dancing with horse whisperers: what horse (wo)men want') that addressed the perennial problem of how to communicate the results of scientific equine research to horse owners. I presented the poster at the 2nd International Equine Science Symposium in Milan. While I was pleased with this interdisciplinary outcome of my research and the kudos from presenting at an international conference, I was simultaneously very uneasy about the direction the research was taking. It seemed that the method and not the research question was now driving the project. I was fast approaching a crossroad in my research journey and it was time to look up and take action in order to avoid a wreck.

Because data wrangling was relatively easy I was (briefly) tempted to concentrate on the science and abandon the creative aspects of the project. Most of the reasons for this stemmed from my lack of conviction about the 
creative aspects of the project. Although both my training and instincts had equipped me for creative writing, by this stage I had read so many stories about women and their horses that I questioned whether the world needed any more, and felt disinclined to add mine to the pile. Instead, I wanted to produce something thicker, more thoughtful and more creative; but I had no idea what that something might be. The data had taken on a life of its own and was now dominating the project, and yet I couldn't see how to integrate it into a creative dissertation. Similarly, the Milan poster represented a considerable investment of my resources - both financial and intellectual - but I was stumped about how to put it to work in a creative fashion. Caught in the interface between theory and practice I felt like a fraudulent pseudo-scientist trapped in a creative body; or was it the other around?

I made reference to this identity crisis in a paper I presented to the AAWP Conference Postgraduate Day in Brisbane in December 2006. In it I drew upon Plato's chariot allegory as a metaphor to demonstrate my struggle to control my project. I likened myself to the charioteer responsible for reining in the runaway black data/exegetical horse, while at the same time urging on the white horse of creativity. I described how my horses often pulled against each other, while I alternately hauled on the reins and brandished the whip in the hope that the pair, like the exegesis and the creative work, would eventually settle down and work together. I commented at the time that, unlike Plato, I prefer a light hand on the reins and would never flog a horse, but as this was Plato's allegory I had no business tinkering with it. When the time came to rewrite that paper this apparently throwaway comment continued to niggle at me until I decided it was time to step back and reconsider just what I was trying to achieve.

By referring to Plato I had in fact committed a dual fraud. Unlike more informed scholars (see Dibble), I know very little about Plato, and so my application of the chariot allegory was a thin conceit that not only cut hard at the heart of my personal ethic of horsemanship, but also, because life and art are connected, compromised the integrity of my research. By inadvertently separating theory from practice I had fallen into a trap where, in the words of Stuart Hall 'you don't really translate it, you just borrow it, renovate it, play at recasting it' (cited Johnson 2004: 93). The resulting imbalance reflected a growing but unwelcome bifurcation in the research project that reflected a lack of sincerity and authenticity, because it was the absolute antithesis to my personal holistic practice of life and living. In looking for cause and effect and ways to mesh all the parts into a synchronised whole, a hybrid approach to problem-solving proved to be a more productive logic.

\section{Horse practice and research practice}

In her keynote address to the 2006 University of Queensland WIP Conference, Gay Hawkins championed the hybrid, the peripatetic and the speculative as necessary to creativity (Hawkins 2006). For a horsewoman, this approach makes tremendous sense. Successful horse/human relationships are the product of creative horsemanship. The once-pervasive hierarchical model of horse training, steeped in theories of domination and control, is currently being replaced by a more egalitarian approach that uses communication and cooperation; in my case, this is a hybrid blend of techniques and methods. While I am a relative newcomer to the field of creative practice at the doctoral level, I have had a lifetime to develop a personal philosophy of ethical horsemanship, and it was this that led me to perceive the parallels between creative research and creative horsemanship. Key elements include sowing the 
seeds of an idea and waiting to see what emerges; remaining true to the feminist qualities of both research and the practice of natural horsemanship; and embracing the subjective and embodied aspects of both enterprises. By applying the same philosophy to my research project as I would to a green (inexperienced) horse-in-training, I rediscovered the path that would lead to the end of my journey.

\section{Emergent}

Creative practice, like creative horsemanship, is neither linear, nor formulaic nor sequential. Rather, as action research theorist Anne Inga Hilsen argues, it is a cycle of reflection and action which can be either liberating or constricting (Hilsen 2006). For me, trained to look for and reward the slightest attempt from my horse, the possibilities inherent in this process proved fruitful. For example, instead of confronting the data problem head-on, I simply turned it out for a spell after Milan while I concentrated on other required aspects of the dissertational process. Spurred on by the Milan experience, I submitted abstracts to several upcoming conferences and discovered that, for me, writing conference papers prompted new ways of thinking about the horse/woman bond. Furthermore, I found I had things to say that fell outside my self-imposed exegetical parameters and, as a consequence, I was forced to find a creative way to incorporate these opinions into the dissertation.

The solution not only solved the dilemma of what to do about the creative work, but also provided a space for my own voice. This was an important breakthrough because up to this point I felt I should be foregrounding the horsewomen who were the subjects of my research. In allowing my own voice to be heard I acknowledged that my multiple roles in the project were not only legitimate, but necessary in terms of authenticity. I decided to write a collection of reflective essays with topics emerging not only from the chrysalis of the conference papers, but also from the Milan poster and from the data. For example, I discovered from my questionnaire survey that fear is a recurring theme in the horse/woman bond and I addressed this in a creative essay that was subsequently published in a peer-reviewed journal. When I finally brought the data back in to work, I was able to look at it with fresh eyes and found new ways to fit it to the research instead of allowing it to dominate the project. This proactive pause was both enriching and productive. A latent creativity emerged that added more depth, complexity and shades of meaning to both the exegesis and the creative product. I stepped back and saw that, like a maturing young horse, my project was becoming more shapely, more balanced and harmonious. Better still, I was beginning to understand and respond to its idiosyncrasies and, in finding a way to reconnect to my research, I no longer felt like a fraud.

\section{Feminist Practice}

Australian academic Estelle Barrett contends that 'An often vexed issue in creative arts research is related to establishing the work in an identifiable location within the broader arena made up of more clearly defined disciplines or domains of knowledge' and that this is 'crucial to the design and development of research projects' (Barrett 2005). My holistic worldview initially precluded me from being open to the idea of laying down theoretical borders. I have a philosophical resistance to labelling. To name a horse 'lazy' or 'stupid' is so limiting in terms of expectations for change and growth. Similarly, I was reluctant to limit the potential of my creative project by confining it to a 
single theoretical pigeonhole. This may be a reaction to the current political climate expressed by Moya Costello, who says that 'Under neoliberalism something has stuck hard on borders, against fluidity and boundlessness' (Costello 2005).

It wasn't until I started to recognise the correlations between the practices of horsemanship and research and the objects of my research that I realised that this principled stance was actually hindering my progress. Here I was attempting to explain female knowledge of a particularly female experience not only from an objective but also from a subjective point of view, while failing to see that, without a theoretical framework, my work had no valid context. Given the gendered nature of my research and my own gendered experiences, a feminist framework was naturally appropriate. In teaching my horse a new skill I would have to translate an intellectual theory into a practice of doing, and in a similar way, feminist communication theory seeks to 'make connections between concepts and lived experience, between observations and knowledge and between thought and action' (Rakow \& Wackwitz 2005: 6).

Furthermore, as I learnt more about female ways of being with horses I realised they exhibit many of the hallmarks of feminist research practice. It is on one level intuitive, innate and instinctive. It is a process of negotiation with no absolute rights or wrongs. It is a world populated by multiple others - the otherness of horses, of other horsewomen, of horse and rider combinations and all the permutations that evolve from their multiple interactions. Similarly my project is composed of multiple others, including the horsewomen who are object and subject, as well as my own multi-faceted roles in the project. We are all afforded a voice. Horsemanship is not a hard science, but a series of narratives shot through with shades of meaning and possible interpretations. It is relational and nurturing and it acknowledges the validity of emotional responses. Horses are family, treated with affection, consideration, respect; and horsewomen openly express love for their horses. Ken Plummer speaks, in reference to critical humanism, of 'a feminist ethics of care and compassion' and of 'love' as a feminist value (Plummer 2005: 361). It is clear to me that the same feminist values existed in my research as in my horsemanship. The only sticking point is the actual term 'horsemanship'. Ontologically the term excludes no one but it carries a gendered baggage that fails to reflect the numerical ascendancy of horsewomen over horsemen. The alternative 'horsewomanship' doesn't really work for me - it's too contrived and pedantic. Along with a renewed feminist imperative, we need a new language; but, for the time being, horsemanship will have to do.

\section{Subjectivity and Embodiment}

As the project progressed I became increasingly aware of the need to clarify my own position in relation to the research. Fisher and Phelps contend that 'the explanation of the origin of the research and the justification for it need lie not in the literature but in the personal narrative of the particular researchers' (Fisher \& Phelps 2006: 156) and this is certainly true for both my horsemanship and my creative project. I accept that, by asking about Australian horsewomen, I am actually asking about my own place in this particular sector of society or, to reiterate Ken Plummer, 'What follows is partly an attempt to make sense of my own experiences with friends' (Plummer 2005: 362). Poet Alicia Ostriker's claim that 'the self in its innermost regions is plural. That the "I" is a "we"' (Ostriker 2005: 78) aptly describes the subjective position of cultural researchers, a notion eloquently expressed as the 'collectivity of individual experience and the individuality of collective experience [that] seek 
multiple understandings to give coherence (Rakow \& Wackwitz 2005: 7).

Estelle Barrett uses the expression 'embodied cultural capital' (Barrett 2005) to describe creative arts research as motivated by personal interests and subjective concerns based on lived experiences rather than on an objective

disinterestedness. This viewpoint is supported by Kamberelis and Dimitriadis who posit that there is 'no easy separation between the researcher and the researched' (Kamberelis and Dimitriadis 2005: 902) and by McLeod who claims that the creative researcher is permitted to be visibly present in the research, and accepts the self as an interactive component (McLeod, cited Dally et al 2004). Both Kerri Brandt (1995: 13-21) and Audrey Wipper (2000: 54-55), who research horse/human interactions, furnish eloquent defences of their positions as embedded researchers, citing the value of bringing their deep knowledge, judgement and understanding to the research. My take on embedded researchers is less about validation, and more concerned with the integrating possibilities of such an essentially embodied approach. There are many striking similarities between embodied horsemanship and embedded researchers.

There is physicality in the horse/women bond. One body surrounds another, contact is often skin to skin, breath to breath; it's tactile and sensuous, yet goes beyond physical touch to something more instinctive - a form of embodiment. It seems to me totally appropriate that research into such an embodied undertaking as horse/human relations should be approached in an equally embodied manner by acknowledging that the researcher is as much a part of the research as a woman is a part of the horse she rides. Understanding ways in which knowledge is always already embodied - corporeally, viscerally, and materially - raises possibilities for thinking differently (Lather, cited by Radway in Kamberelis and Dimitriadis 2005: 901). This realisation opened up my thinking about the centrality of my presence in the project. I am both the rider with all the responsibilities of person-in-charge and, at the same time, part of this embodied being, the horse and rider together. I ignore my horse's wishes at my peril. If I don't allow her a voice she will become dull or resentful and harmony will be lost. We will simply become two opposing creatures working against each other. And this is how I came to understand that through my interpellation as the subject-writer (Webb 2000) I am the link between the exegesis and the creative, and the thread that binds all the parts of this project together is me.

\section{Finding a voice, finding solutions}

Left to her own devices, my horse would most probably choose to stand under a tree with her herd mates. Equally, without my agenda Australian horsewomen would in all likelihood remain unexamined. It is my presence, my agenda that not only makes this particular piece of research unique, but also makes it possible. As my insights into the compositional integrity of my research evolved, a plethora of voices emerged. At times it was like standing in the middle of a herd of horses all communicating with each other on different levels - some neighing, some whickering quietly, there were coughs and grunts and snuffles and the steady champ, champ, champ of teeth grinding food. So this is what research sounds like.

I observe and absorb it from my multiple subject positions. I am sender and receiver, observer and observed, subject and object interpreter and creator in constant conversation, exchanging sounds, images, thoughts and actions. My voice, however, is not necessarily always the loudest. The exegesis, for example, contains one half of this conversation. It is the locus for the voices of 
other horsewomen. The loudest voices here belong to the Australian horsewomen who responded to my survey, who shared their stories and opinions in interviews and conversations, on whom I eavesdropped and who I observed. In the background is the hum of a more universal cohort of horsewomen recorded in text and on film, and interjecting here and there are those academic rationalists and theorists attempting to make sense of this world. I am present, walking quietly among them, culling and selecting, organising and arranging, bringing their stories to the fore.

Bouncing off these stories are the creative essays, a place where my voice is louder, a little more insistent. The creative section is a receptacle for the other half of the conversation, the one where my voice is heard - responding, arguing, persuading, suggesting another point of view. I am, as Woods says, 'influenced by and influencing the audience, critics and readers, part of a continuous relational flux' (Woods 2007).

In this way I see the dissertation as, to paraphrase Frieman, a site for the social interaction between writers, readers, the creative and exegetical (Frieman, cited Arnold 2005: 43). I challenge my readers to recognise their own stories while engaging with the dissertation on multiple levels. I see the exegetical/creative product simultaneously enmeshed and independent, just as a horse and rider are two different beings and the sum of both beings.

\section{Conclusion}

Despite so much having been written about creative practice, roadmaps are rare. Certainly there are faint traces where others have gone before, but in the end, because creative projects are so intensely personal and subjective, each practitioner must find their own way in the world. While academic guidelines preclude creative practice from existing in a vacuum, sometimes the real challenge for practitioners is to develop a personal research ethos and then find the confidence to practice within the parameters of that ethos. Practitioners may make sense of their own practice by finding parallels in other areas of their lives. This has certainly been my experience. Whenever I took a wrong turn in my research journey I found that returning to the known put me back on course. In my case this place of confidence and knowing is my practice of horsemanship, which infuses all the other aspects of my life with meaning as well as furnishing ways to stay connected to my research. In adopting a similar approach I suggest that other creative postgraduates may not only resist losing their way, but they may also become similarly attuned to the emergence of creative solutions.

\section{Works cited}

Arnold, J 2005 'The PhD in creative writing accompanied by an exegesis', Journal of university teaching and practice, 1.2: 36-50, at http://jutlp.uow.edu.au/ (accessed 13 November 2005) return to text

Barrett, E 2005 'Creative arts practice, creative industries: method and process as cultural capital' (unpublished transcript) return to text

Booth, K 2007 'Humans as animal: the cosmology of hairy underarms', Animals and Society

Conference, Hobart (unpublished paper) return to text 
Brandt, K 1995 Intelligent bodies: Women's embodiment and subjectivity in the human-horse communication process. PhD dissertation, Ann Arbor, Michigan return to text

Costello, M 2005 '"Irrigorous uncertainties": writing, politics and pedagogy', TEXT 9.1, at http://www.griffith.edu.au/school/art/text/april05/costello.htm (accessed 16 April 2006) return to text

Dally, K Holbrook, A Lawry, M and Graham, A 2004 'Assessing the exhibition and the exegesis in visual arts higher degrees: perspectives of examiners', in Working papers in art and design 3, at http://www.herts.ac.uk/artdes/research/papers/wpades/vol3/kdfull.html (accessed 9 March 2006) return to text

Dibble, B 2006 'Disinterested passion: Creative writing and the arts of love and teaching', in N Krauth and T Brady (eds), Creative writing: theory beyond practice, Teneriffe, Qld. Post Pressed, 109-19 return to text

Fisher, K and R Phelps 2006 'Recipe or performing art? Challenging conventions for writing action research theses', Action research 4.92: 143-64 return to text

Gibbs, A 2006 'Writing and danger: The intercorporeality of affect', in N Krauth and T Brady (eds), Creative writing: theory beyond practice, Teneriffe, Qld. Post Pressed, 157-67

Guest, G 2005 'Snorters and chucklers', Artlook, November, 10 return to text

Hawkins, G 2006 'Thinking with things: Polar bears, potatoes and plastic bags'. Keynote Address, Prefixing, 19th Annual WIP Conference, 24-25 September, School of EMSAH/University of Queensland return to text

Hilsen, AI 2006 'And they shall be known by their deeds: Ethics and politics in action research', Action Research, 4.1: 3-36 return to text

Johnson, R Chambers, D Raghuram, P and Tincknell, E 2004 The practice of cultural studies, London, Sage Publications return to text

Kamberelis, G and Dimitriadis, G 2005 'Focus groups: Strategic articulations of pedagogy, politics and inquiry' in NK Denzin and YS Lincoln (eds), The Sage handbook of qualitative research (3rd ed), Thousand Oaks, CA: Sage, 887-914 return to text

Kroll, J 2006 'Redrafting the self: the author as a work in progress', in N Krauth and T Brady (eds), Creative writing: theory beyond practice, Teneriffe, Qld. Post Pressed, 197-209

Milech, BH \& A Schilo 2004 "'Exit Jesus": relating the exegesis and creative/production components of a research thesis', TEXT Special Issue 3, April, at http://www.griffith.edu.au/school/art/text/speciss/issue3/milechschilo.htm (accessed 28 July 2006) return to text

Nelson, R 2004 'Doctoralness in the balance: The agonies of scholarly writing in studio research degrees', TEXT Special Issue 3, April, at http://www.griffith.edu.au/school/art/text/speciss/issue3/nelson.htm (accessed 28 July 2006)

Ostriker, A 2005 'Stealing the language' (excerpt), in D Brown, A Finch \& M Kumin (eds), Lofty dogmas: Poets on poetics, Fayetteville: University of Arkansas Press, 75-78 return to text

Plummer, K (2005). 'Critical humanism and queer theory: Living with the tensions', in Norman K Denzin and Yvonna S Lincoln (eds). The Sage handbook of qualitative research 3rd ed, Thousand Oaks, CA, Sage: $357-385$. return to text

Rakow, LF and LA Wackwitz 2005 Feminist communication theory: selections in context, Thousand Oaks, CA: Sage return to text

Ryan, A 2005 'Connecting two research strategies: A hybrid model', TEXT 9.1, April, at http://www.gu.edu.au/scool/art/text/april05/ryan.htm (accessed 16 April 2005) return to text

Saukko, P 2003 Doing research in cultural studies, London/Thousand Oaks, CA: Sage return to text 
Webb, J 2000 'Individual enunciations and social frames', TEXT 4.2, October, at http://www.griffith.edu.au/scool/art/text/oct00/wwebb.htm (accessed 16 April 2005) return to text

Wipper, A 2000 'The partnership: the horse-rider relationship in eventing', Symbolic Interaction 23.1: $47-70$ return to text

Woods, C 2007 'Making strange with bold moves - what next for student, supervisor and examiner? Or, no blueprint: assessing the (creative) exegesis'. TEXT 11.1, April, at http://www.griffith.edu.au/school/art/text/april07/woods.htm (accessed 27 June 2007) return to text

Sandra Burr is a PhD candidate in the School of Creative Communication at the University of Canberra researching the bond between women and horses. Sandra has presented aspects of her research to a variety of forums including The International Equine Science Symposium in Milan, September 2006, the UnAustralia Conference in Canberra, December 2006, the Animals \& Society Conference in Hobart, July 2007 and the Hawkesbury Regional Art Gallery, August 2007. She has had her work published in refereed journals and the popular press.

\section{TEXT}

Vol 11 No 2 October 2007

http://www.textjournal.com.au

Editors: Nigel Krauth \& Jen Webb

Text@griffith.edu.au 